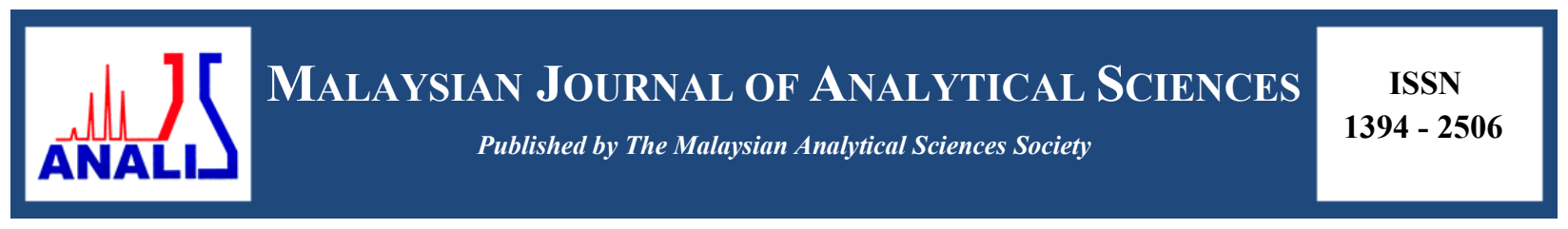

\title{
ZETA POTENTIAL AND ENVIRONMENTAL SCANNING ELECTRON MICROSCOPY ANALYSIS IN DEPROTEINISATION OF NATURAL RUBBER LATEX
}

\author{
(Analisis Keupayaan Zeta dan Pengimbas Persekitaran Mikroskopi Elektron di dalam \\ Penyahprotein Lateks Getah Asli) \\ Nurulhuda Abdullah*, Asrul Mustafa, Mok Kok Lang \\ Technology and Engineering Division, \\ Malaysian Rubber Board, 47000 Sungai Buloh, Selangor Darul Ehsan, Malaysia \\ *Corresponding author: nurulhuda.a@lgm.gov.my
}

Received: 10 june 2015; Accepted: 21 July 2016

\begin{abstract}
This paper describes the effect of protein denaturants namely, urea and sodium dodecyl sulphate (SDS) in the deproteinisation of high ammonia natural rubber latex (HA-NRL). It had been shown that latex proteins were reduced more in the presence of urea alone $(48 \%)$ than in the presence of SDS (18\%). The synergistic effect when both urea and SDS were used in the latex deproteinisation attributed to the higher protein removal efficacy (55\%). Higher zeta potential value was observed when only SDS was used, suggesting higher colloidal stability. Environmental Scanning Electron Microscopy (ESEM) revealed that without SDS, the use of urea single-handedly in the deproteinisation process promoted aggregation of latex particles, possibly due to the dismissal of latex proteins which helped to stabilise latex colloidal. Thus, it is most likely that urea serves as a protein unfolding agent during latex deproteinisation process, while SDS functions as a latex stabiliser with no significant effects on latex proteins discharge.
\end{abstract}

Keywords: urea, sodium dodecyl sulphate, deproteinisation, zeta potential, environmental scanning electron microscopy

\begin{abstract}
Abstrak
Kertas kerja ini menghuraikan kesan bahan-bahan pengubah sifat protein iaitu urea dan natrium dodekil sulfat (NDS) dalam penyahprotein lateks getah asli tinggi ammonia (HA-NRL). Ia telah menunjukkan bahawa protein lateks lebih banyak dikurangkan dengan kehadiran urea sahaja (48\%) berbanding dengan kehadiran NDS sahaja (18\%). Keberkesanan penyingkiran protein yang lebih tinggi (55\%) mungkin telah disebabkan oleh kesan sinergi apabila kedua-dua urea dan NDS digunakan di dalam penyahprotein lateks. Nilai keupayaan zeta yang tinggi diperhatikan apabila hanya NDS digunakan, menunjukkan kestabilan koloid yang lebih tinggi. Pengimbas Persekitaran Mikroskopi Elektron (ESEM) menunjukkan bahawa tanpa NDS, penggunaan hanya urea dalam proses penyahprotein menyumbang kepada kesan pengagregatan zarah lateks, kemungkinan disebabkan oleh penyingkiran protein lateks yang membantu dalam kestabilan koloid lateks. Oleh yang demikian, besar kemungkinan fungsi utama urea semasa proses penyahprotein lateks adalah sebagai ejen pembuka protein manakala NDS berfungsi sebagai penstabil lateks tanpa kesan ketara pada penyingkiran protein lateks.
\end{abstract}

Kata kunci: urea, natrium dodekil sulfat, penyahprotein, keupayaan zeta, pengimbas persekitaran mikroskopi elektron

\section{Introduction}

Natural rubber (NR) latex in general can be defined as a material that consists stable dispersion of polyisoprene rubber (hydrocarbon) and a large number of non-rubber constituents mainly carbohydrates, lipids, and proteins in an 
aqueous serum phase. These non-rubber constituents are dissolved, freely suspended in the aqueous phase or absorbed on the surface of rubber particles [1-3]. During latex concentrate processing through centrifugation for instance, most of the smaller latex particles are removed together with the non-rubbers present in the serum. It is known that not all non-rubbers can be removed completely during the centrifugation process hence commercially supplied NR latex still contains considerable amounts of non-rubbers.

In its native state, NR latex contains about $6 \%$ of non-rubbers and the content is reduced to more than half during processing. However, the presence of non-rubbers is regarded imperative not only in conferring stability of rubber latex but also in governing the properties of end products. Any modification in the rubber composition may result in deterioration of properties especially in vulcanisation and cure characteristics [4]. The presence of proteins and other non-rubber linkages are also presumed to provide outstanding mechanical properties of rubber due to straininduced crystallisation characteristic [5].

On the other hand, the presence of proteins is responsible for certain undesirable properties in NR for instance poor creep, storage hardening, high moisture absorption and poor stress relaxation behaviour [6-7]. Detrimental effects of proteins present in NR were reported in several studies [8-10]. The high moisture uptake in NR is presumably due to interaction of proteins and phospholipids at the terminal chains of rubber with water (moisture). It is generally established that the hardening phenomenon of rubber is attributed to the inter-chain crosslink formation. Proteins and phospholipids at the chain-ends of rubber molecules may interact with water under ambient condition, leads to disruption for branching points due to hydrogen bonding. Thus, when water is removed from the rubber, both functional groups at the terminal chains of rubber will undergo chain-branching and crosslinking which contribute to the gel formation during storage hardening behaviour [10].

The development and production of low protein latexes and products are an important research area ever since the emergence of allergy issues attributed to the latex proteins. Allergic responses are triggered by extractable proteins present in NR latex products especially rubber gloves. Malaysia as one of the largest exporters of latex products is affected by the negative perception of NR latex. Therefore, research in NR latex deproteinisation has continued to balance out the desirable properties which associated with rubber proteins and at the same time to eliminate the adverse proteins.

Generally, proteins can be easily destabilised and its destabilisation is determined by a balance of many competing factors. By nature, a functional native protein is in a folded (F) structure conformation [11-12] and when it loses the conformation $(\mathrm{F})$, it ceases to function. The unfolding $(\mathrm{U})$ process of proteins is called protein denaturation. The stability of protein can be easily affected by slight changes in temperature, pressure or solvent conditions. For instance, the presence of even a small organic molecule in aqueous solution can have profound effect on protein stability, structure, and function. In nature, this occurrence enables the proteins to either retain its stability or promote destabilisation indirectly by controlling the conformational equilibrium between folded $(\mathrm{F})$ to the unfolded (U) structures.

Deproteinisation of NR latex can be achieved using protein denaturants. Urea has a long good reputation as protein denaturant owing to its ability to denature proteins by causing it to unfold. This denaturant has been described elsewhere [13] to produce low protein NR latex. Another common chemical used in latex deproteinsation is sodium dodecyl sulphate (SDS) which is an anionic surfactant $\left[\mathrm{CH}_{3}\left(\mathrm{CH}_{2}\right)_{11} \mathrm{OSO}_{3} \mathrm{Na}\right]$. Owing to the synergistic effect between both chemicals, effective proteins removal was described [14]. It is proposed in urea-SDS protein denaturation mechanism (Figure 1), urea may unfolded the proteins while SDS binds onto the surface of unfolded proteins and imparts negative charges, resulting in the protein to have higher net negative charge compared to its previous state. This phenomenon then creates electrostatic forces which cause the proteins to unfold into rod like shape. The unfolded proteins are then removed during the centrifugation process.

To the best of our knowledge, further elucidation on individual functions of urea and SDS or the combination of both during NRL deproteinisation is obscured hence creating a gap in knowledge. Thus, the aim of this paper is to explicate and address aforesaid gap in scientific knowledge. 


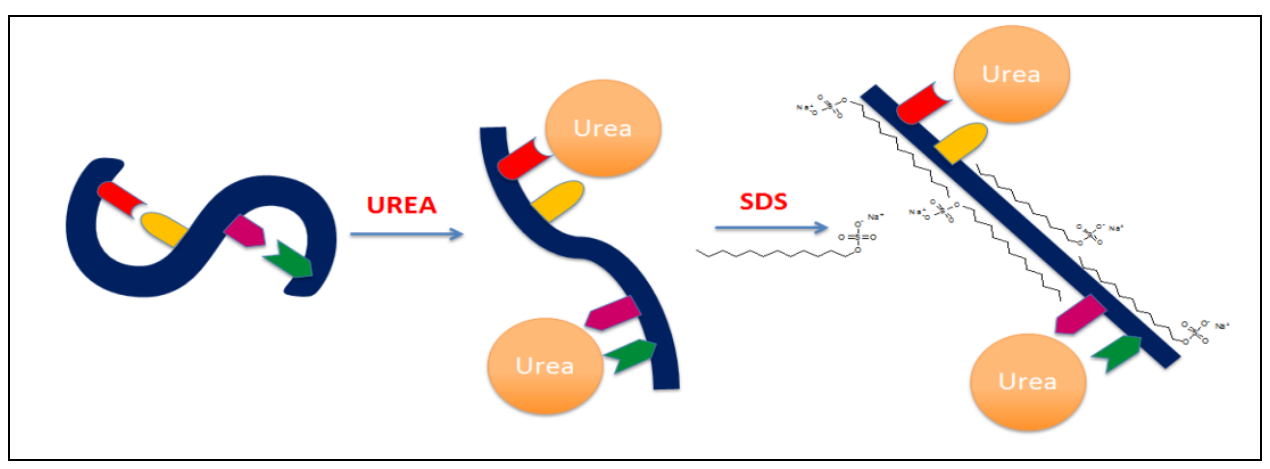

Figure 1. Proposed mechanism on simple protein denaturation via urea - SDS combination treatment

\section{Preparation of deproteinised latex}

\section{Materials and Methods}

Commercial high ammonia NR latex (HA-NRL) was used for deproteinisation. HA-NRL was incubated with $0.1 \%$ urea $(\mathrm{w} / \mathrm{w})$ in a mixing vessel under continuous stirring for 1 hour prior to centrifugation. Centrifugation was carried out using the Beckman Coulter Ultracentrifuge Model Optima L-100K at 9,000 rpm and $15^{\circ} \mathrm{C}$. After centrifugation, the cream fraction was collected and redispersed with distilled water followed by addition of SDS $1.0 \%(\mathrm{w} / \mathrm{w})$. The redispersed cream fraction was stirred for 30 minutes and centrifugation was carried out for the second time. The resulting cream fraction was again collected and redispersed with distilled water to $30 \%$ total solid content. The same procedure was repeated for latex treated using $1.0 \%$ SDS only and a combination of $0.1 \%$ urea with $1.0 \%$ SDS respectively.

\section{Characterisation}

The protein content in latex samples was determined using the Kjeldahl method which measured the total nitrogen content. About $0.1 \mathrm{~g}$ of sample was first weighed and digested in a micro Kjeldahl flask, followed by steam distillation. The distillation result was titrated with concentrated sulphuric acid. The nitrogen content was determined in triplicates and calculated from the titration values.

Particle size and zeta potential of latex were determined using the Brookhaven 90Plus/BI-MAS ZetaPlus. The latex was diluted to $0.01 \%(\mathrm{w} / \mathrm{w})$ before use. For the Environmental Scanning Electron Microscopy (ESEM), samples were prepared by adding approximately a drop of latex into $1 \mathrm{ml}$ distilled water in Eppendorf tubes. The mixtures were centrifuged and the supernatants discarded. The latex samples were then stained with $1 \%$ osmioum tetroxide before viewing under ESEM.

\section{Protein contents and zeta potentials}

\section{Results and Discussion}

The proteins content and zeta potential characteristic of HA-NRL which were treated with different combinations of either urea, SDS or both denaturants (samples A, B, and C) are tabulated in Table 1. It is evident that the deproteinisation process resulted in a considerable reduction in protein content of the treated latexes.

Evidently, latex treated with urea (sample A) demonstrated approximately $49 \%$ protein removal compared to the untreated HA-NRL. In the presence of SDS alone (sample B), only $18 \%$ reduction in proteins content was seen. This suggests that SDS might have smaller role and capacity to denature proteins compared to urea.

Urea is found capable to denature proteins by binding onto the protein peptide backbone via hydrogen bonding to the polar moieties of proteins [15-17]. It is also reported elsewhere [18] that urea readily promotes solvation of protein hydrophobic groups whereby partial solubility of hydrocarbon was seen in the presence of aqueous urea. These elements could have contributed to the greater removal of latex proteins, resulted when urea was used, in comparison to SDS in the present study. 
Table 1. The effect of protein denaturants on zeta potential and protein content

\begin{tabular}{llll}
\hline Treatments & $\begin{array}{l}\text { Sample } \\
\text { Reference }\end{array}$ & $\begin{array}{l}\text { Proteins } \\
\text { Content }(\mathbf{\%})\end{array}$ & $\begin{array}{l}\text { Zeta Potential } \\
(\mathbf{m V})^{\mathbf{1}}\end{array}$ \\
\hline High ammonia natural rubber latex (control) & HA-NRL & 3.88 & -40.78 \\
HA-NRL treated with 0.1\% urea & A & 1.99 & -25.85 \\
HA-NRL treated with 1.0\% SDS & B & 3.18 & -31.32 \\
HA-NRL treated 0.1\% urea and 1.0\% SDS & C & 1.75 & -46.32 \\
\hline
\end{tabular}

${ }^{1}$ Zeta potential measured at $\mathrm{pH} 10$

From the perspective of SDS, interaction of the anionic surfactant with proteins may also cause denaturation via high affinity binding. SDS is an anionic surfactant which may bind to proteins via sulphate group and positively charged amino side chain, or between the alkyl chain and hydrophobic side chain [19]. An earlier study [19] suggested that the protein unfolding process via SDS might proceed via two different modes which are closely linked to the changes in the micellar structures. That study also established that concentration of surfactants played an important role in the degree of unfolding of the proteins.

This present study shows that the combination of both denaturants resulted in highest protein removal efficacy (55\%). However, this is only an increment of about $6 \%$ compared to latex treated with urea alone. This slight increment in urea-SDS protein removal indicates a synergistic effect from the two denaturants. Urea may inhibit the effectiveness of SDS to unfold proteins as it is found that in the presence of urea, the SDS hydrocarbon tails readily solvate, aggregation number of SDS micelles reduced and CMC value of SDS increased [18]. Therefore, to further enhance protein removal efficiency, it is suggested that higher than $1 \%$ of SDS is required.

With regard to electrostatic stability, the lower protein content resulted from deproteinisation of HA-NRL with urea caused a substantial reduction in zeta potential value from $-40.78 \mathrm{mV}$ to $-25.85 \mathrm{mV}$. Zeta potential analysis gives an indication on surface charge behaviour on rubber particle surface, thus distinct chemical nature of the absorbed layers on the surface of rubber particle is reflected in the difference in the zeta potential value consequently the colloidal stability of natural rubber latex. Adsorbed proteins on the surface of latex particle are reported to contain both acidic and alkaline functional groups that carry positive and negative charge respectively [20]. HA-NRL is composed of phospholipids, carbohydrates, proteins and other non-rubber constituents which contribute charge species that gives high negative zeta potential value [3]. Perturbation of the proteins layer by urea might compensate the surface charge hence compressed the diffuse layer and subsequently reduced the negative zeta potential value [20].

According to the theory of adsorption isotherm [21], charged surfactant like SDS will adsorb onto the surface of latex particles. Reduction in zeta potential value was observed when HA-NRL was treated with $1 \%$ SDS. Zeta potential of latex treated with SDS was better than latex treated with urea, suggesting that the former has better colloidal stability than the latter. Interestingly, a higher zeta potential value was observed for sample $C$ which was treated with urea in the presence of SDS whereby its zeta potential surpassed that of HA-NRL alone. This again suggests the synergistic effect of both denaturants when they are used together in deproteinisation of latex.

\section{Factors influencing particle size distribution}

Figure 2 depicts particle size distribution of samples HA-NRL, A, B and C. Monomodal size distribution was observed for all samples. Similar size distribution was observed for samples HA-NRL and A, while B and C showed bigger size distributions with sample B recorded the biggest result. Although the proteins content and zeta potential value of sample A were prominently reduced, the particle size distribution was not affected much compared to control (HA-NRL). The narrower and obvious shift to bigger size distribution for sample B (treated with $1.0 \%$ SDS) could be due to encapsulation of SDS onto the latex particles which resulted in interference and restricted penetration by photon correlation spectroscopy used in the size measurement method. Moreover due to the 
function of SDS as stabiliser, a more distinct and stable domain of rubber particle was formed which restricted interparticle fusion. This explains the reason why particle size distribution for sample B is narrower and shifted to bigger particle size range.

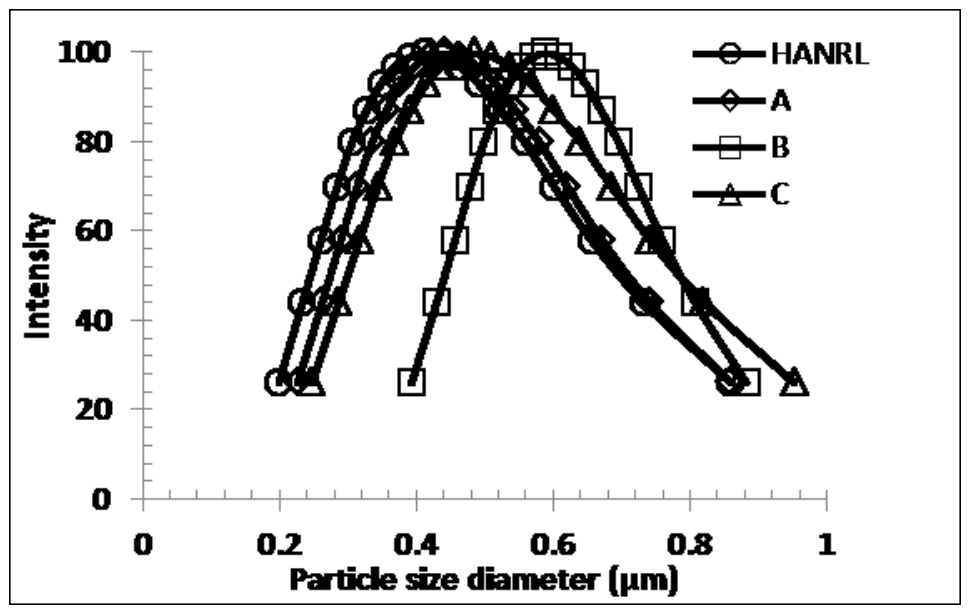

Figure 2. Effect of individual chemical treatment and combination of both chemicals on particle size diameter of deproteinized NRL $(\mathrm{A}=\mathrm{HANRL}$ treated with $0.1 \%$ urea, $\mathrm{B}=$ HANRL treated with $1.0 \%$ SDS, and $\mathrm{C}=$ HANRL treated with $0.1 \%$ urea and $1.0 \%$ SDS)

Morphological changes in the treated latex samples were studied using ESEM as shown in Figure 3. The micrographs were obtained at 15,000 to 21,000 magnification levels. As observed, rubber particles for all samples exhibited nearly spherical shape. HA-NRL showed strong aggregation of rubber particles with large variation in the size distribution. After the centrifugation process, the smaller rubber particles were removed and the latex particles sizes became more uniformed (Figure $3 \mathrm{~b}$ and $3 \mathrm{~d}$ ). In the presence of urea alone (Figure $3 \mathrm{~b}$ ), the particles were observed to favour particle inclusion; this may be due to the weakening of the hydrophobic forces when the proteins layers were depleted. In the presence of SDS, the degree of aggregation was less (Figure $3 \mathrm{c}$ and $3 \mathrm{~d}$ ). This was due to SDS role which served as a protective layer substituting function of the eliminated proteins. Hence, rubber particles in the presence of SDS were able to preserve their distinctive shape and remained well separated.
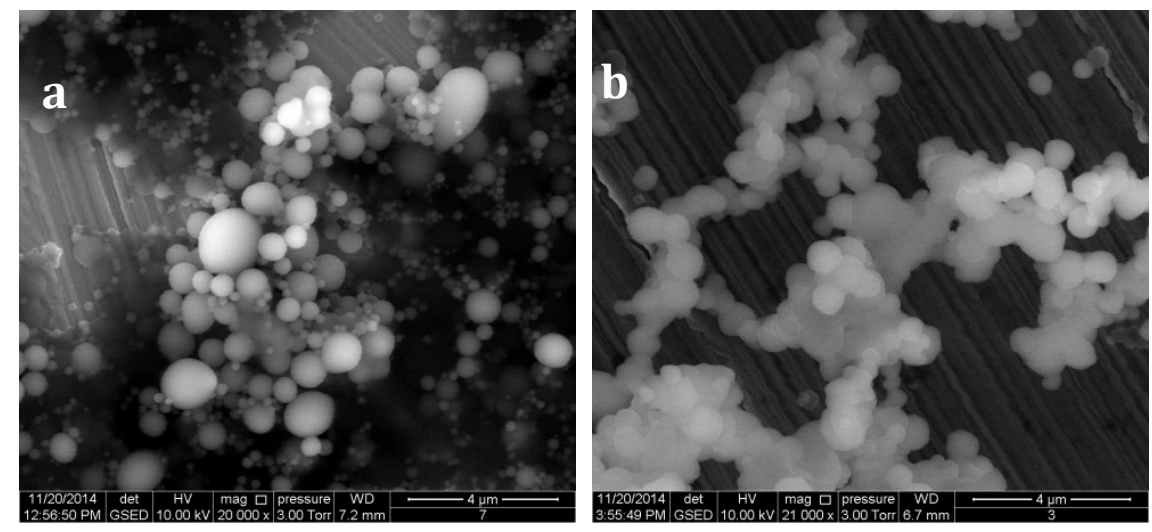

Figure 3. ESEM morphological image of a) HANRL, b) HANRL treated with $0.1 \%$ urea, c) HANRL treated with $1.0 \%$ SDS and d) HANRL treated with $0.1 \%$ urea and $1.0 \%$ SDS 
It is worth to notify that the primary reason of conducting ESEM analysis is to understand and to have a quick look on the behaviour of rubber particle in a wet condition especially during deproteinisation. This method allows us to gather more information on their shape rather than sizes. The number of particle measured in ESEM is normally small hence it is difficult to collect enough data to give more reliable particle size result. Moreover, it is hard to determine whether or not the particles are merged and aggregated and they will often consider as bigger particle size.

Schematic illustrations on the deproteinisation process using urea, SDS and urea in presence of SDS are shown in Figure 4. It is hoped that this figure will clarify and demonstrate the mechanism of how the rubber particles assemble during deproteinisation process using urea and SDS. The removal of proteins from the surface of rubber particles by urea may create weakens hydrophobic forces of protein layer [15, 22], hence resulting to the merging of rubber particles with adjacent particles (Figure 4a). However, as mentioned earlier, it is uncertain whether the particles are permanently attached together or just in contact with adjacent particle. Treatments with urea will not break the proteins but serves as denaturants which facilitates the removal of proteins from NRL through centrifugation and washing process [23]. When only SDS was used during deproteinisation process, the particle seemed to have an orderly arrangement with a distinct particle shapes and without the particles merging effect (Figure 4b). Interaction of SDS surfactant with NRL surface can be demonstrated as strong interacting systems [24] thus enhance the colloidal stability of rubber particles. This phenomenon will keep the particles away from another therefore particles are well separated. Again, less aggregation was observed when urea and SDS were used mutually (Figure 4c), suggesting the particles protective layer imparted by adsorption of SDS on rubber particle surface.
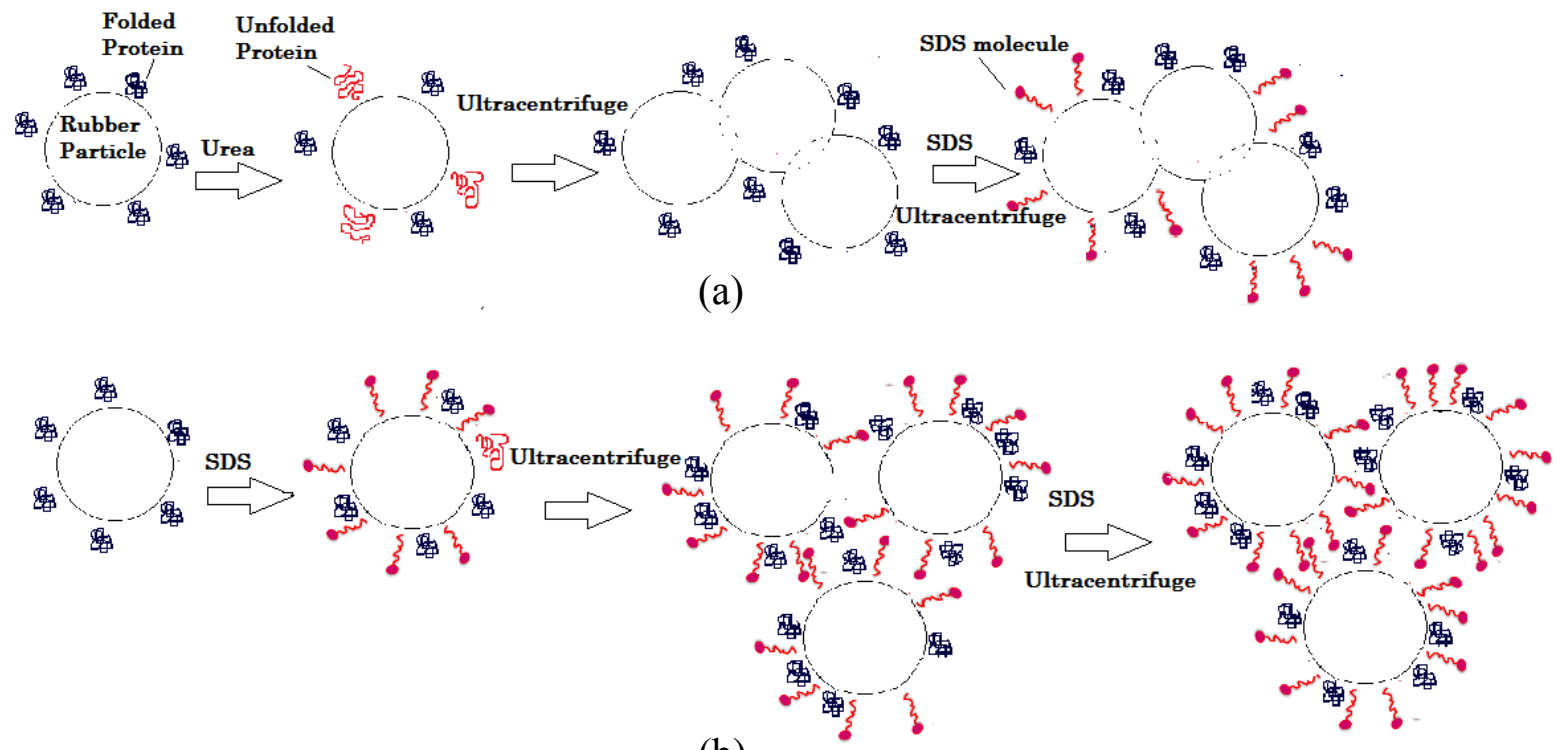

(b)

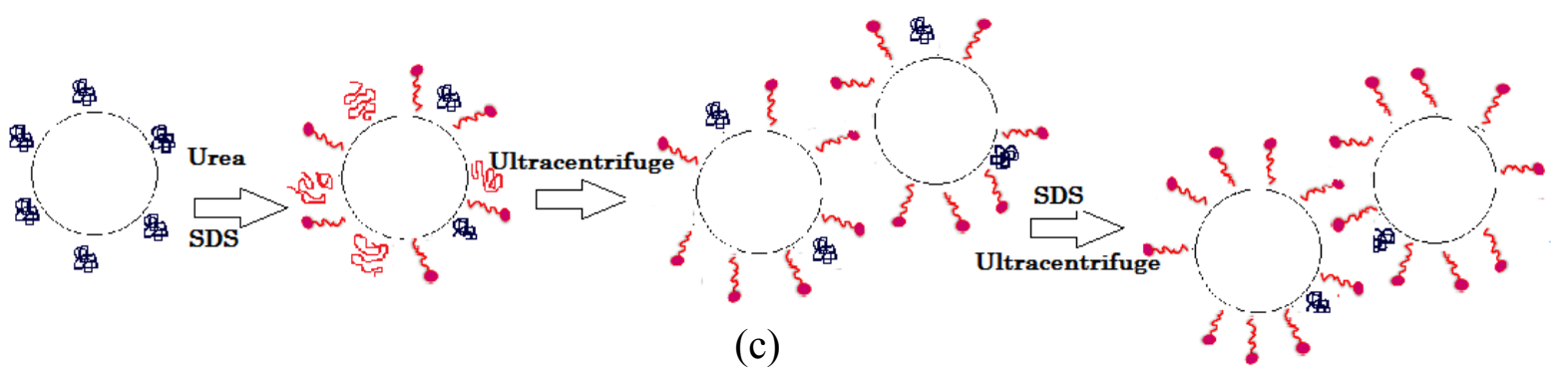

Figure 4. Proposed mechanism and morphological changes during deproteinisation of NRL using a) urea b) SDS and c) urea in the presence of SDS 


\section{Conclusion}

The function of each denaturant used in the deproteinisation of NRL was examined. This study shows that urea serves as a protein unfolding agent, eliminating the rubber protein protective layer and consequently disrupts the latex colloidal stability, hence promoting particle fusion. The presence of SDS improves the colloidal stability of latex by preserving the colloidal shape of particle and restricting fusion of particle via encapsulation of the rubber particles. This study suggests that in the deproteinisation process, it is most likely that urea functions as a protein unfolding agent whilst SDS serves as a latex stabiliser without distinct effect in the removal of latex proteins.

\section{Acknowledgement}

The authors would like to thank the Director General of the Malaysian Rubber Board for permission to publish findings of this study.

\section{References}

1. Hasma H. and Subramaniam A. (1986). Composition of lipids in latex of Hevea brasiliensis clone RRIM 501, Journal Natural Rubber Research, 1(1):30 - 40.

2. Aprem A. S. and Pal S. N. (2002). Latex allergy and recent developments in deproteinisation of natural rubber latex Journal of Rubber Research, 5(2): 94 - 134.

3. Sansatsadeekul, J., Sakdapipanich, J. and Rojruthai, P. (2011). Characterization of associated proteins and phospholipids in natural rubber latex. Journal of Bioscience and Bioengineering, 111(6): 628 - 634 .

4. Ma'zam Md Said, Ng, K. P., Hasma, H., Mok, K. L., Asrul, M., Lai, P. P. and Saadiah, S. (2004). Low protein natural rubber lattices. Journal of Rubber Research, 7(1): 30 - 55.

5. Amnuaypornsri, S., Sakdapipanich, J., Toki, S., Hsiao, B. S., Ichikawa, N. and Tanaka, Y. (2008). Straininduced crystallization of natural rubber: effect of proteins and phospholipids. Rubber Chemistry and Technology, 81(5): $753-766$.

6. Nor-Hidayaty, K., Shamsul, K., Asrul, M. and Ahmad-Nazir, K. (2011). Comparisons of some properties of deproteinised natural rubber vulcanisates and observations on dynamic load analysis. Journal of Rubber Research, 14(3): 129 - 138.

7. Othman, A. and Hasma, H. (1988). Influence of Hevea proteins and amino-acids on properties of natural rubber, Proceedings International Rubber Technology Conference: 166 - 177.

8. Burfield, D. R. (1986). Storage hardening of natural rubber: An examination of current mechanistic proposals. Journal of Natural Rubber Research, 1(3): 202 - 208.

9. Sakdapipanich, J. T. (2007). Structural characterization of natural rubber based on recent evidence from selective enzymatic treatments. Journal of Bioscience and Bioengineering, 103(4): 287 - 292.

10. Sakdapipanich, J. T. and Rojruthai, P. (2012). Molecular structure of natural rubber and its characteristics based on recent evidence. InTech publisher: pp. $159-172$.

11. Creighton, T. E. (1995). Protein folding: An unfolding story. Current Biology, 5(4):353-356

12. Creighton, T. E. (1979). Electrophoretic analysis of the unfolding of proteins by urea. Journal of Molecular Biology, 129: 235 - 264.

13. Yamamoto, Y., Kawahara, S., Chaikumpollert, O. and Nghia, P. T. (2013). Protein- free natural rubber, latex thereof, and method for manufacturing said rubber and US Patent 8476348 B2

14. Kawahara, S., klinklai, W., Kuroda, H. and Isono, Y. (2004). Removal of proteins from natural rubber with urea. Polymer Advance Technology, 15:181 - 184.

15. Rossky, P. J. (2008). Protein denaturation by urea: Slash and bond. PNAS, 105(44): 16825 - 16826.

16. Canchi, D. R., Paschek, D. and García, A. E. (2010). Equilibrium study of protein denaturation by urea. Journal of the American Chemical Society, 132(7): 2338 - 2344.

17. Bennion, B. J. and Daggett, V. (2003). The molecular basis for the chemical denaturation of proteins by urea. PNAS, 100 (9): 5142 - 5147.

18. Ruiz, C. C. (1999). Micelle formation and microenvironmental properties of sodium dodecyl sulphate in aqueous urea solution Colloids and Surfaces A: Physicochemical and Engineering Aspects, 147: 349 - 357.

19. Otzen, D. E. (2002). Protein unfolding in detergents: Effect of micelle structure, ionic strength, pH, and temperature. Biophysical Journal, 83: 2219 - 2230. 
20. Kemp, A. R. and Straitiff, W. G. (1940). Hevea Latex: Effect of proteins and electrolytes on colloidal behavior. Rubber Chemistry and Technology, 13(4): 705 - 721.

21. Chen, S. F. (1981). Adsorption of sodium dodecyl sulfate on natural rubber latex particles and determination of specific surface area of the particles. Rubber Chemistry and Technology, 54(1): $124-133$.

22. Jacso, T., Bardiaux, B., Broecker, J., Fiedler, S., Baerwinkel, T., Mainz, A., Fink, U., Vargas, C., Oschkinat, H., Keller, S. and Reif, B. (2013). The mechanism of denaturation and the unfolded state of the $\alpha$-helical membrane-associated protein Mistic. Journal of the American Chemical Society, 135(50): 18884 - 18891.

23. Junoi, S., Chisti, Y. and Hansupalak, N. (2015). Optimal conditions for deproteinizing natural rubber using immobilized alkaline protease Journal of Chemical Technology and Biotechnology, 90: 185 - 193.

24. Wei, L. K., Ing, W. K., Badri, K. H. and Ban, W. C. (2013). Formation of protein complex with the aid of polyethylene glycol for deproteinized natural rubber latex AIP Conference Proceedings 1571: 871 